\title{
Effect of Neem Cake Urea Mixed Application on Growth and Yield of Rice under Submerged Condition
}

\author{
Harish Shenoy* \\ Department of Agronomy, Livestock Research and Information Centre (Amrithmahal), \\ Konehalli-572201, Tiptur, Tumkur district, Karnataka, India \\ (Karnataka Veterinary Animal and Fisheries Sciences University, Bidar Karnataka) \\ *Corresponding author
}

\section{A B S T R A C T}

\begin{tabular}{|l|}
\hline Ke y w o r d s \\
Rice, Neem cake, \\
Urea mixture, \\
Growth, Yield, \\
Submerged \\
\hline Article Info \\
\hline $\begin{array}{l}\text { Accepted: } \\
18 \text { March } 2020 \\
\text { Available Online: } \\
\text { 10 April } 2020\end{array}$ \\
\hline
\end{tabular}

A field experiment was carried out during kharif, 2016 at the farm of ICAR-Krishi Vigyan Kendra (KVK), Mangaluru, Karnataka state to study the effect of neem cake urea mixed application on growth and yield of rice under submerged condition. The soil of the experimental field was lateritic with acidic $\mathrm{pH}$, medium in available nitrogen, high in phosphorus and low in potassium content. The experiment was laid out in randomized block design with seven treatments and each one replicated thrice. The treatments composed of absolute control, $100 \%$ nitrogen along with five treatment of urea and neem cake mixed in different propositions. The results indicated that number of tillers per $\mathrm{m}^{2}$, number of panicles per $\mathrm{m}^{2}$ and plant height $(\mathrm{cm})$ was significantly higher in treatment $\mathrm{T} 3$ comprising $100 \%$ RDN in three splits) with $100 \%$ Neem cake application followed by treatment T4 comprising $75 \%$ RDN with $100 \%$ neem cake application compared to other treatments. The grain yield and straw yield was significantly higher T3-RDN (100\%) in three splits + Neem cake (100\%) followed by T4- RDN $(75 \%)+$ Neem cake $(100 \%)$. The lowest grain yield and straw yield was recorded in treatment $\mathrm{T} 1$-Control where nitrogen was not applied.

\section{Introduction}

Rice (Oryza sativa $\mathrm{L}$ ) is one of the important cereal crops of the world occupying $11 \%$ of the agricultural land and ranks second in terms of cultivated area (Tumrani et al., 2015). Globally Rice is grown in an area of 162 million ha with a production of 461 million tons and productivity is 4.09 tons/ha (Anonymous, 2015). In India, Rice is grown in an area of 43.19 million ha with a production of 110.15 million tons (Anonymous, 2017).

Though rice production continues to play a vital role in the national food and livelihood security of the system, the productivity of rice is only $2.55 \mathrm{t} / \mathrm{ha}$ (milled rice) which is less compared to global productivity of $3.28 \mathrm{t} / \mathrm{ha}$ (Anonymous, 2018) increasing the 
productivity of rice remains the main challenge considering that the $90 \%$ of the cultivated area of rice belong to small and marginal farmers. The most feasible way by which this could be achieved is by adopting a more integrated approach involving water nutrients and other agronomic factors for maximizing the rice grain yield (Gobi et al., 2016).

Among the nutrient inputs nitrogen ranks first to maximize the output in agriculture. Nitrogen is the key nutrient element required in large amounts for rice and provision of adequate supply of $\mathrm{N}$ throughout the growing period is necessary for realizing potential yields (Sureka et al., 2016). Nitrogen promotes rapid plant growth and improves grain yield and grain quality through higher tillering, leaf area development, grain formation, grain filling and protein synthesis (Pratap Reddy et al., 2019). Though the yield increase due to $\mathrm{N}$ fertilization in rice has been substantial (47\%), the average agronomic efficiency of $\mathrm{N}$ is only $11.4 \mathrm{~kg}$ grain $/ \mathrm{kg} \mathrm{N}$ (Prasad, 2011) and nitrogen use efficiency is only (30-50\%) due to losses of nitrogen under flooded condition (Johri and Yadav, 2006). Slow-release fertilizers (SRF) are often used to increase nitrogen-use efficiency (Prasad $e t$ al., 1998). SRFs are designed to release $\mathrm{N}$ over an extended period of time, rather than all at once, in an attempt to better match plant $\mathrm{N}$ needs throughout the growing season and to reduce time of exposure for $\mathrm{N}$ losses to the environment (Ellison et al., 2013).

However the farmers continue to rely on split dosages and use urea as primary source of nitrogen (Bhalla and Deviprasad, 2008). Low cost alternative to slow release fertilizers include use of plant derived organic substances like neem cake, green leaf manure and Pongamia extract. Many of them exhibit nitrification inhibition property (Devkumar and Goswami, 1992). The neem cake obtained after oil extraction contains 5\% nitrogen and is used as manure and making neem coated urea (Subbalakshmi Lokanadhan, 2012). Urea constitutes about $82 \%$ of the fertilizer nitrogen $(\mathrm{N})$ used in India. Neem coated urea has been observed to improve nitrogen use efficiency and subsequently crop yield in rice (Pratap Reddy et al., 2019). Nitrification inhibitors like neem cake when applied along with urea reduces losses of applied nitrogen, thereby resulting in an improved yield of crops. The efficiency of nutrient may be improved by combined use of organic neem cake with inorganic source of nitrogen fertililizer namely urea. Hence a study was conducted to know the effect of neem cake urea mixed application on growth and yield of rice under submerged condition.

\section{Materials and Methods}

A field experiment was conducted during kahrif-2016 in the farm of ICAR-Krishi Vigyan Kendra, Mangaluru, Karnataka to study the effect of neem cake urea mixed application on yield and yield attributes of rice. The experimental site is located at 12 " 50 'N latitude and 75"14' E longitude in coastal Karnataka. The soil of the experimental site was lateritic characterized by acidic $\mathrm{pH}$ (5.5) having Electrical conductivity of $0.14 \mathrm{dSm}^{-1}$. The soil organic carbon was $1.52 \%$, the available nitrogen was medium (380kg/ha), available phosphorus (97.4kg/ha) was high and available potassium was $(96.13 \mathrm{~kg} / \mathrm{ha})$ was low. During the crop growth period from june to October 2016, a rainfall of $2751 \mathrm{~mm}$ was received compared to normal rainfall of $3245 \mathrm{~mm}$ during the same period. The experiment was laid out in randomized block design (RBD) replicated thrice. There were totally seven treatments comprising of five neem cake and urea mixed application in various combinations along with one control and one treatment comprising application of recommended dose 
of nitrogen in form of urea. The treatments were T1- Control $\left(\mathrm{N}_{0} \mathrm{P}_{30} \mathrm{~K}_{60}+\right.$ No Neem cake), T2- sole RDF ( $\left.\mathrm{N}_{60} \mathrm{P}_{30} \mathrm{~K}_{60}\right)$, T3- $100 \%$ RDN $\left(\mathrm{N}_{60} \mathrm{P}_{30} \mathrm{~K}_{60}\right)+$ Neem cake $(100 \%)$, T4- $75 \%$ RDN ( $\left.\mathrm{N}_{45} \mathrm{P}_{30} \mathrm{~K}_{60}\right)+$ Neem cake (100\%), T5$50 \% \quad \mathrm{RDN} \quad\left(\mathrm{N}_{30} \mathrm{P}_{30} \mathrm{~K}_{60}\right) \quad+$ Neem cake (100\%), T6-50\% RDN $\left(\mathrm{N}_{30} \mathrm{P}_{30} \mathrm{~K}_{60}\right)+$ Neem cake (75\%), T7- 50\% RDN $\left(\mathrm{N}_{30} \mathrm{P}_{30} \mathrm{~K}_{60}\right)+$ Neem cake $(50 \%)$. The rice variety used was MO-4 maturing in 130-135 days. The recommended dose of fertilizers was applied at the rate of $60 \mathrm{~kg} \mathrm{~N} / \mathrm{ha}, 30 \mathrm{kgP}_{2} \mathrm{O}_{5}$ and $60 \mathrm{~kg}$ $\mathrm{K}_{2} \mathrm{O}$. The source of nitrogen used was urea $(46 \% \mathrm{~N})$ applied in three split dose $(33 \%$ each split) at planting, tillering and panicle initiation stage.

The Neem Cake (@ 1.25 tons/ha (100\%) and Farm Yard Manure (5.0 tons/ha) was applied at time of land preparation before planting. Phosphorus was applied in form of rock phosphate at one dose at time of planting and potassium was applied in three splits @ 33\% each combined with nitrogen source urea. Observations were recorded at harvest and the treatment means were compared using least significant difference at 5\% level of significance. (Gomez and Gomez, 1984)

\section{Results and Discussion}

The results of effect of neem cake urea mixed application on growth and yield of rice under submerged condition is presented in Table 1 .

\section{Growth and yield attributing characters}

The results indicated that the treatment T3$100 \%$ RDN $\left(\mathrm{N}_{60} \mathrm{P}_{30} \mathrm{~K}_{60}\right)$ in three splits (planting, tillering and panicle initiation stage) with Neem cake $(100 \%)$ recorded significantly higher plant height $(107.3 \mathrm{~cm})$ compared to other treatments of various combinations of urea and neem cake application but was on par with treatment T4$75 \%$ RDN $\left(\mathrm{N}_{45} \mathrm{P}_{30} \mathrm{~K}_{60}\right)+$ Neem cake $(100 \%)$ which recorded $106.4 \mathrm{~cm}$. The lowest plant height $(93.0 \mathrm{~cm})$ was recorded in T1control where neem cake and nitrogen source was not applied. This was followed by treatment T2 sole RDF $(100.3 \mathrm{~cm})$ where only nitrogen was applied. All the urea neem cake mixed application treatments recorded significantly higher plant height than control and could be attributed to higher availability of nitrogen resulting in promoting vegetative growth of rice. Similar findings were also reported by Kumar et al., (2015).

The application of increasing dose of nitrogen significantly increased the number of tillers per $\mathrm{m}^{2}$ in rice. The treatment T3 comprising of $100 \%$ RDN $\left(\mathrm{N}_{60} \mathrm{P}_{30} \mathrm{~K}_{60}\right)$ with $100 \%$ Neem cake recorded significantly higher number of tillers per $\mathrm{m}^{2}$ (472) compared to other treatments of urea and neem cake mixed application. However this treatment was on par with treatment T4- application of $75 \%$ RDN $\left(\mathrm{N}_{45} \mathrm{P}_{30} \mathrm{~K}_{60}\right)$ with $100 \%$ Neem cake which recorded 468 tillers $/ \mathrm{m}^{2}$. The other treatment combinations of neem cake and nitrogen application were on par with each other but significantly higher than treatment T1-control $\left(\mathrm{N}_{0} \mathrm{P}_{30} \mathrm{~K}_{60}+\right.$ No Neem cake) which recorded only 320 tillers per $\mathrm{m}^{2}$ ) also reported Similar increase in rice tillers per $\mathrm{m}^{2}$ by use of neem coated urea was also reported by earlier workers (Raj et al., 2014 and Neha Khandey et al., 2016) and could be attributed to higher availability of nitrogen which enhanced tillering.

The number of panicles per $\mathrm{m}^{2}$ was significantly influenced by different levels of nitrogen application with neem cake and followed similar trend as observed in number of tillers per $\mathrm{m}^{2}$. The highest number of panicles per $\mathrm{m}^{2}$ (445) was recorded in treatment T3 comprising of $100 \% \mathrm{RDN}$ $\left(\mathrm{N}_{60} \mathrm{P}_{30} \mathrm{~K}_{60}\right)$ with $100 \%$ Neem cake application which significantly differed compared to $\mathrm{T} 1$ - Control $\left(\mathrm{N}_{0} \mathrm{P}_{30} \mathrm{~K}_{60}\right.$ without 
Neem cake application (286) and treatment T2 comprising Sole RDF ( $\mathrm{N}_{60} \mathrm{P}_{30} \mathrm{~K}_{60}$ ) without Neem cake application (380). However, treatment $\mathrm{T} 3$ was on par with treatment $\mathrm{T} 4$ comprsing of $75 \%$ RDN $\left(\mathrm{N}_{45} \mathrm{P}_{30} \mathrm{~K}_{60}\right)$ with application of $100 \%$ Neem cake (442). The other treatments of urea neem cake mixture in various proportions namely T5 (410), T6 (398) and T7 (376) recorded significantly higher panicles per $\mathrm{m}^{2}$ than control but were par with each other. Similar findings were also reported by earlier workers (Kumar et al., 2015 and Neha Khandey et al., 2017).

\section{Grain and straw yield}

The grain yield was significantly influenced by neem cake urea mixed application in rice under submerged condition. The grain yield of rice was significantly higher in treatment T3 (55q/ha) comprising of application of $100 \%$ RDN $\left(\mathrm{N}_{60} \mathrm{P}_{30} \mathrm{~K}_{60}\right)$ in three splits (planting, tillering and panicle initiation stage) combined with application of $100 \%$ Neem cake compared to treatment T1-control (38.0 q/ha) and treatment T2- Sole RDF $\left(\mathrm{N}_{60} \mathrm{P}_{30} \mathrm{~K}_{60}\right)+$ No Neem cake (42.0 q/ha) but was on par with treatment $\mathrm{T} 4$ (52q/ha) comprising of $75 \%$ RDN $\left(\mathrm{N}_{45} \mathrm{P}_{30} \mathrm{~K}_{60}\right)$ with $100 \%$ Neem cake. The treatment T5, T6 and T7 recorded significantly higher yield (46q/ha, 45 q/ha and 43 q/ha respectively) than T1-control but were significantly lower than treatments T3 and T4. Higher yield in paddy by application of $100 \%$ NCU (Neem Coated Urea) and $80 \%$ NCU was also reported by Mangat and Narang (2004), Suganya et al., (2007) and Neha khandey et al., (2017)

The straw yield was significantly influenced by neem cake mixed urea application in rice. The maximum straw yield was recorded in treatment T3 (4.35 tons/ha) comprising of $100 \%$ RDN (three splits) with $100 \%$ Neem cake application followed by treatment $\mathrm{T} 4$ (4.28 tons/ha) consisting of $75 \% \mathrm{RDN}$ $\left(\mathrm{N}_{45} \mathrm{P}_{30} \mathrm{~K}_{60}\right)$ with $100 \%$ Neem cake application which were on par with each other but were significantly higher than treatment T1 control (3.46 tons/ha) and treatment T2 (4.07 tons/ha) comprising of application of $100 \%$ RDN without neem cake application.

Table.1 Effect of neem cake urea mixed application on growth and yield of rice under submerged condition

\begin{tabular}{|l|l|c|c|c|c|c|}
\hline $\begin{array}{l}\text { Sl. } \\
\text { No. }\end{array}$ & Treatments & $\begin{array}{c}\text { Plant } \\
\text { height } \\
(\mathbf{c m})\end{array}$ & $\begin{array}{c}\text { Tillers } \\
/ \mathbf{m}^{\mathbf{2}}\end{array}$ & $\begin{array}{c}\text { Panicles } \\
/ \mathbf{m}^{\mathbf{2}}\end{array}$ & $\begin{array}{c}\text { Grain } \\
\text { yield } \\
\mathbf{q} / \mathbf{h a})\end{array}$ & $\begin{array}{c}\text { Straw } \\
\text { yield } \\
\text { t/ha }\end{array}$ \\
\hline $\mathbf{1}$ & T1- Control $\left(\mathrm{N}_{0} \mathrm{P}_{30} \mathrm{~K}_{60}+\mathrm{No}\right.$ Neem cake $)$ & 93.0 & 320 & 286 & 38.0 & 3.46 \\
\hline $\mathbf{2}$ & T2- Sole RDF $\left.\mathrm{N}_{60} \mathrm{P}_{30} \mathrm{~K}_{60}\right)+$ No Neem cake & 100.3 & 421 & 380 & 42.0 & 4.07 \\
\hline $\mathbf{3}$ & T3-100\%RDN $\left(\mathrm{N}_{60} \mathrm{P}_{30} \mathrm{~K}_{60}\right)+$ Neem cake $(100 \%)$ & 107.3 & 472 & 445 & 55.0 & 4.35 \\
\hline $\mathbf{4}$ & T4-75\% RDN $\left(\mathrm{N}_{45} \mathrm{P}_{30} \mathrm{~K}_{60}\right)+$ Neem cake $(100 \%)$ & 106.4 & 468 & 442 & 52.0 & 4.28 \\
\hline $\mathbf{5}$ & T5-50\% RDN $\left(\mathrm{N}_{30} \mathrm{P}_{30} \mathrm{~K}_{60}\right)+$ Neem cake $(100 \%)$ & 103.0 & 428 & 410 & 46.0 & 4.13 \\
\hline $\mathbf{6}$ & T6-50\% RDN $\left(\mathrm{N}_{30} \mathrm{P}_{30} \mathrm{~K}_{60}\right)+$ Neem cake $(75 \%)$ & 102.0 & 426 & 398 & 45.0 & 4.12 \\
\hline $\mathbf{7}$ & T7- 50\% RDN $\left(\mathrm{N}_{30} \mathrm{P}_{30} \mathrm{~K}_{60}\right)+$ Neem cake $(50 \%)$ & 102.0 & 419 & 376 & 43.0 & 4.10 \\
\hline & Sem \pm & 0.63 & 11.1 & 9.44 & 1.31 & 0.04 \\
\hline & $\mathrm{CD}(\mathbf{5} \%)$ & 1.85 & 33.0 & 28.0 & 3.88 & 0.13 \\
\hline
\end{tabular}


The increase in straw yield could be attributed to increased vegetative growth in terms of plant height and number of tillers per $\mathrm{m}^{2}$ which could be attributed to increased nitrogen use efficiency and continuous supply of nitrogen boosting vegetative growth (Sarangi et al., 2016).

Two processes probably contributed to increased nitrogen availability one is inhibition of denitrifying bacteria by neem cake and the other is slow release of nitrogen caused by the binding of urea particles to surface of urea (Wakimoto, 2004).

It can be concluded that the yield attributing characters i.e number of tillers per $\mathrm{m}^{2}$, number of panicles per $\mathrm{m}^{2}$ and plant height (cm) was observed to be significantly higher in treatment $\mathrm{T} 3$ comprising application of $100 \%$ RDN $\left(\mathrm{N}_{60} \mathrm{P}_{30} \mathrm{~K}_{60}\right)$ in three splits with $100 \%$ Neem cake application compared to other treatments.

The grain yield and straw yield was significantly higher in treatment $\mathrm{T} 3$ comprising $100 \% \mathrm{RDN}\left(\mathrm{N}_{60} \mathrm{P}_{30} \mathrm{~K}_{60}\right)$ in three splits with $100 \%$ Neem cake application followed by treatment T4 comprising $75 \%$ RDN $\left(\mathrm{N}_{45} \mathrm{P}_{30} \mathrm{~K}_{60}\right)$ with $100 \%$ Neem cake application The lowest grain yield and straw yield was recorded in control where nitrogen was not applied.

\section{Acknowledgements}

Author is thankful to ICAR- Krishi Vigyan Kendra, Dakshina Kannada District, Mangaluru-575002 Karnataka State, Karnataka Veterinary Animal and Fisheries Sciences University, Bidar-575419, Karnataka, India and ICAR- Agricultural Technology Application Research Institute, Zone-XI, Bengaluru-560024, Karnataka. India.

\section{References}

Anonymous. 2015. FAO Production Statistics Rome: (Food and Agriculture Organization).

Anonymous, 2017. Agricultural Statistics at a Glance. Govt. of India Directorate of Economics and Statistics Ministry of Agriculture and farmer welfare DACFW GOI pp. 36.

Anonymous, 2018 FAO- Rice Market Monitor 21: 1-2.

Bhalla R S and K V Deviprasad, 2008. Neem cake- urea mixed application increase growth in paddy. Current Science, 94(8): 1066-1070.

Devkumar C and Goswami. B K. 1992. Nematicidal principles from neem isolated and bioassay of some melicans. Pesticides Research Journal, 4(2): 7984.

Ellison, E., Blaylock A., Sanchez, C and Smith, R. 2013. Exploring controlled release nitrogen fertilizers for vegetable and melon crop production in California and Arizona Proceedings. Western Nutrient Management Conference. 10: 17-22

Gomez K A and Gomez. A. A.,1984. Statistical Procedures for Agricultural Research $2^{\text {nd }}$ Edition An International Rice Research Institute Book published by John Wiley \& Sons, New York, pp 639

Gobi R, S. Shanmuga Sundaram, A. Balasubramanian and D. Elayaraja, 2018, Effect of Integrated nutrient Management on Nutrient Uptake and Nitrogen use Efficiency in Lowland Rice, Advances in Plant Sciences, 31(2): 113-115.

Johri B N and Yadav J. S. P. 2006, Low and declining crop response to fertilizers. National Academy of Agricultural Sciences Policy paper No. 35.

Kumar Ravendra, Jaiswal Pawan, Kumar Ajit, Kumar Sunil, 2015. Effect of modified 
urea on nitrogen use efficiency, growth and yield of transplanted rice (Oryza sativa L.) var. NDR-359., New Agriculturist. 26:263-266

Mangat G S, Narang J. K. 2004. Agronomical trial for efficacy of NFL Neem Coated Urea. Fertilizer Marketing News. 35 (11) : $1-7$

Neha Khandey, R S Singh, Anurag S, S Sengar and Rahul Kumar, 2017. Response of applied neem coated urea (NCU) on yield and yield attributing parameters of rice (Oryza sativa $\mathrm{L}$ ) in vertisol. International Journal of Chemical Studies 5(4): 1671-1675.

Prasad R, Saxena VC, Devakumar C, 1998. Pusa Neem golden urea for increasing nitrogen-use efficiency in rice, Current Science. 75: 15.

Prasad. R. 2011, Aerobic Rice Systems Advances in Agronomy 111: 207-247.

Prathap Reddy, N. C H. Bharat Bhushan Rao, K. Surekha and Hussain, S.A. 2019. Transplanted Rice as Influenced by Different Enriched Nitrogen Sources-an Economic Appraisal. International Journal of Current Microbiology and Applied Sciences 8 (06): 3229-3231. doi:

https://doi.org/10.20546/ijcmas.2019.80 6.384 .

Raj S K, Bindhu J S, Girjadevi L.2014. Nitrogen availability and uptake as influenced by time of application and $\mathrm{N}$ sources in semi-dry rice (Oryza sativa).
Journal of Crop and Weed. 10:295-302

Suganya S, Appavu K, Vadivel A. 2007. Relative efficiency of neem coated urea products for rice grown in different soils. An Agriculture Journal of Soil Science. 2: 29-34

Subbalakshmi Lokanadhan, P. Muthukrishnan and Jeyaraman, S. 2012. Neem products and their agricultural applications. Journal of Biopest, 5 (Supplementary): $72-76$

Sarangi, S.K., Maji, B., Singh, S., Srivastava, A.K., Singh, U.S and Sharma, D.K. 2016. Nitrogen management through neem coated urea and application method further improve rice productivity in coastal flood-prone rainfed lowland. International Agronomy Congress. 2(4): 22-26.

Surekha K R, Mahendra Kumar V, Nagendra N, Sailaja T, Satyanarayana, 2016, 4R nitrogen management for sustained rice production better crops. South Asia, pp. 18-19.

Tumrani, S A., Pathan, P A. and Suleman, B M. (2015) Economic contribution of rice production and food security in Indonesia. Asia Pacific Research Journal 33: 63-74.

Wakimoto, K. 2004. Utilization advantages of controlled release of nitrogen fertilizer on paddy rice cultivation. Japan Agricultural Research Quarterly 38:1520

\section{How to cite this article:}

Harish Shenoy. 2020. Effect of Neem Cake Urea Mixed Application on Growth and Yield of Rice under Submerged Condition. Int.J.Curr.Microbiol.App.Sci. 9 (04): 2224-2229. doi: https://doi.org/10.20546/ijcmas.2020.904.266 